Rapp. Grønlands geol. Unders. 48, 99-104 (1972)

\title{
PRELIMINARY RESULTS OF MAGNETIC INVESTIGATIONS IN THE SCORESBY SUND REGION
}

\author{
Torben Bidstrup
}

\begin{abstract}
Introduction
A magnetic survey comprising both terrestrial and ship-borne work was carried out during the summer 1971 in three phases. During the first phase magnetic profiles were established across the central parts of the Mesozoic sedimentary Jameson Land basin and the bordering Caledonian crystalline complexes. The aim of these investigations was to obtain a geophysical evaluation of the thickness of the sediments and to investigate the contact relations between the crystalline and the sedimentary rocks. The second phase comprised ship-borne investigations along several profile lines across Hall Bredning and Scoresby Sund in order to determine the southern extension of the Mesozoic sediments and their relation to the Tertiary basalts in the south. The westwards extension of the sediments and their boundary relations to the crystalline rocks were investigated in the northern part of Hall Bredning. The third phase made up only a minor part of the programme. This aimed at identifying the possible existence of a few Tertiary volcanic units in Fønfjord predicted from investigations of the surrounding basalts.

Jens Spaabæk, who participated in both field and laboratory investigations, is acknowledged for his great share of the work.
\end{abstract}

\section{Terrestrial survey in central Jameson Land}

Magnetic investigations were carried out along four linear profile lines indicated on fig. 15. The profiles crossed through Permian arkoses and calcareous rocks in the north-west (Kempter, 1961) and through Triassic-Jurassic sandy and argillaceous sediments in the central and eastern part of the sedimentary basin (Surlyk \& Birkelund, this report). The sediments are in places cut by Tertiary basaltic dykes and sills, but the magnetic profile lines were chosen to avoid these. The profile lines extend into migmatites west of the sediments (Henriksen \& Higgins, 1970) and into granitic plutonic rocks east of the sediments (Coe \& Cheeney, this report).

An Askania magnetometer (a torsion magnetometer) was used as a portable 
field instrument for this part of the survey, whereas a proton magnetometer, kept in the camp, was used for reference to correct for daily variations.

Enlarged maps on a scale of 1:50,000 and aerial photographs served as a base for the geographical determination of the profile lines and the measuring points. Along the profile lines measurements were carried out, approximately at kilometre intervals along the short lines and at $3 \mathrm{~km}$ intervals on the long profile.

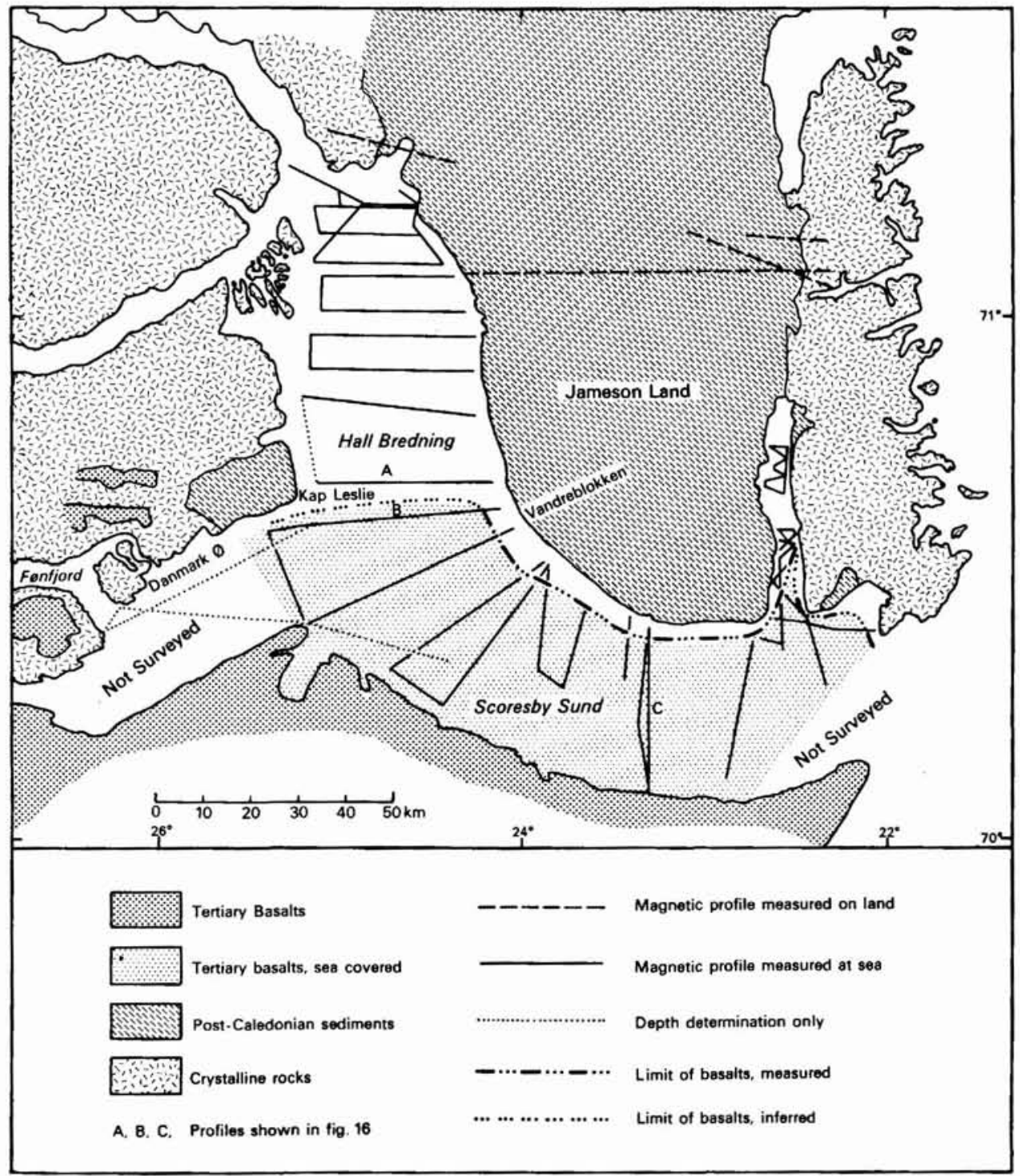

Fig. 15. Sketch-map showing magnetic profile lines and the extent of sea covered basalts. 
The magnetic results indicate the presence of a fault below the sediments near the boundary to the crystalline rocks in the east. The existence of a fault limit between sediments and crystalline rocks in the west was confirmed by the magnetic investigations. It is the aim of continued laboratory investigations to reach an estimate of the thickness of the sedimentary strata in central Jameson Land.

\section{Ship-borne survey in Scoresby Sund and Hall Bredning}

Continuous magnetic profiles were recorded in the fjords along a series of lines between Jameson Land and the neighbouring areas with crystalline and basaltic rocks (fig. 15). The work was carried out from a 160 tons Norwegian wooden ship, m/s "Brandal", which also served as a supply ship for the expedition. The magnetic observations were made with a proton magnetometer. The probe was towed after the ship at a distance of about a hundred metres to avoid interference from the bulk of the ship. Observations were continuously recorded graphically. At the same time as magnetic observations were carried out at sea the daily magnetic variations were recorded by a stationary observation post on shore near the starting point of the profile line measured. This terrestrial reference observation was made with the Askania instrument. Radio contact between ship and land ensured a time co-ordination between the two observation sites.

The navigation on the ship was carried out by standard methods using compass and visual bearings to prominent features on land. The recording of the positions and sailing routes was cross-checked by interval photos of the screen of the Marconi radar, which had a maximum range of 40 nautical miles. Time marks on recorded magnetic and positional data were used to correlate the two. It is estimated that the radar positioning makes it possible to establish a position in the middle of the fjord within $\pm 2 \%$ of the distance across the fjord.

A continuous depth profile was recorded on the "Atlas" echo sounder along all magnetic profiles, and along a few additional lines. The echo sounder used had a range of up to 1100 metres.

The magnetic survey in the fjords has immediately made it possible to determine the northwards extension of the basalts due to the strong magnetic contrast between basalts and other rocks. The boundaries between sediments and crystalline rocks, however, have not revealed a similar contrast and an interpretation of these results is not possible without application of a complex numerical model. These last calculations are not yet complete and the general results of this part of the investigations are not yet available for publication. It is, however, expected that the southward extension of the Stauning Alper fault line, limiting the Jameson Land basin to the west, will be traceable through parts of northern Hall Bredning.

The extension of the basalts below Scoresby Sund and the southern parts of Hall Bredning is indicated on fig. 15. The northern limit forms a line parallel to the 

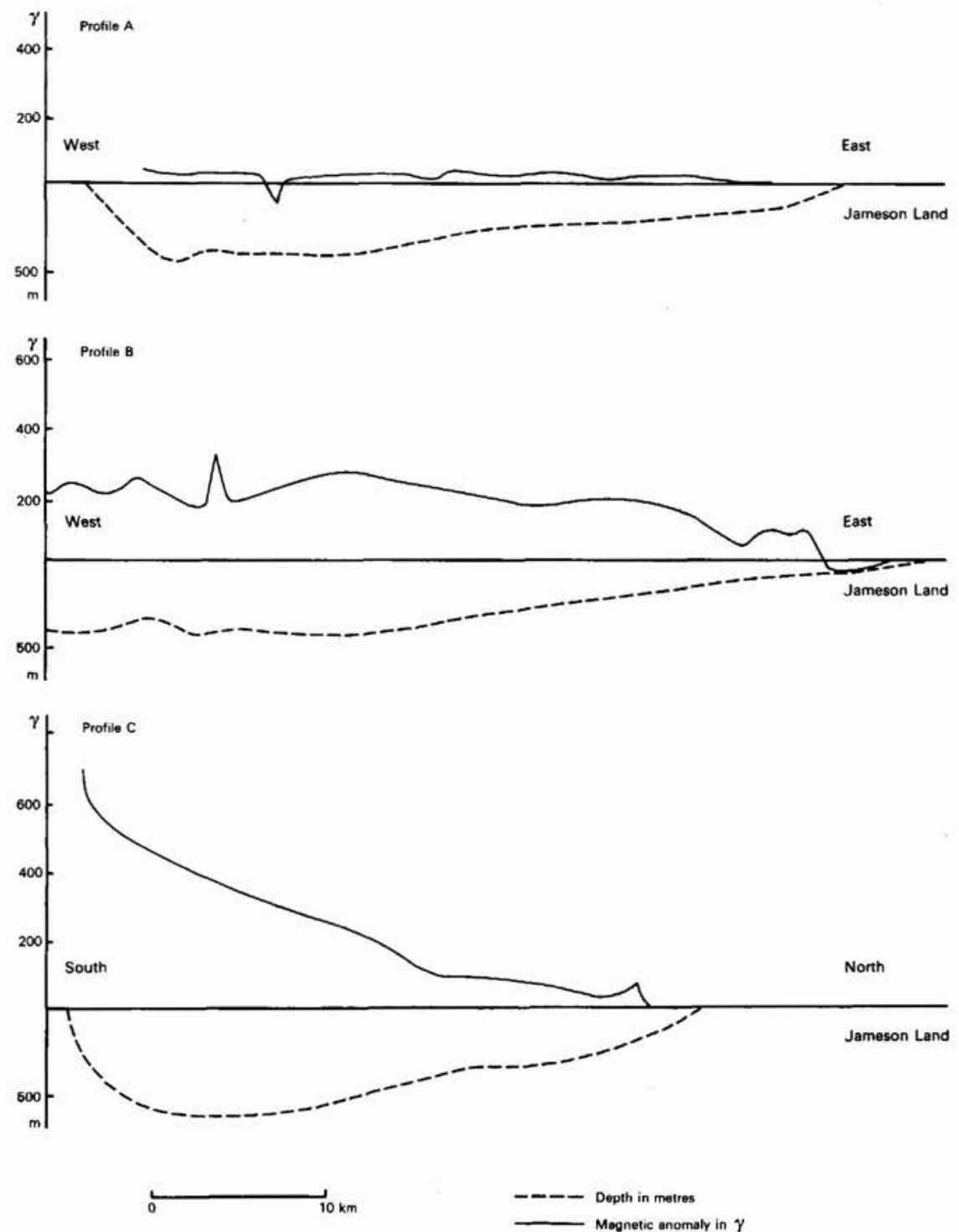

Fig. 16. Sketch of three combined magnetic and depth profiles. Profile lines are indicated on fig. 15.

coast of south Jameson Land, and in Hall Bredning the basalts can be traced northwards to a line approximately between Kap Leslie and Vandreblokken. The parallelism between the coastline and the northern limit of basalts south of Jameson 
Land is significant and it is likely that there exists causal relation between them.

A sketch of three combined magnetic and depth profiles is shown in fig. 16 as examples of the results obtained. The profile lines are indicated on fig. 15; they comprise one profile north of the basalts and two through the basalt area. The depth profiles are generally similar in all three profiles whereas the magnetic anomalies are clearly different. The variation is interpreted as indicating a difference in the substratum.

Profile A connects two areas of sediments and does not indicate the existence of any significant anomaly along the profile. Profile B, taken approximately $10 \mathrm{~km}$ south of A, reveals a completely different magnetic picture. Shortly west of the Jameson Land coast the magnetic anomaly rises sharply and remains at a relatively high value along the rest of the profile farther west. The difference in magnetic intensity between A and B is interpreted as indicating a geological boundary between the two profiles. High magnetic values are also obtained from the profiles in the southern part of Hall Bredning and in Scoresby Sund. The magnetic intensities increase gradually away from the coast of the sedimentary areas. Profile $\mathrm{C}$ is an example of such a profile, where the magnetic anomaly increases sharply immediately south of the Jameson Land coast and gradually increases farther south reaching a maximum just north of the approximately $2000 \mathrm{~m}$ high precipitous basalt coast on the south side of Scoresby Sund.

From profile $\mathrm{C}$ it is seen that the magnetic anomaly just south of Jameson Land shows a small maximum which southwards is followed by a gentle rise. This feature is interpreted as a rim-effect of a thin magnetic layer wedging out over a non-magnetic substratum.

The overall interpretation of the magnetic anomalies in Scoresby Sund and southern Hall Bredning indicates that the basalts extend northwards as far as the line indicated on fig. 15 and that the thickness of the basalts decreases gradually northwards. It is expected that the Jameson Land sediments continue at least for some distance south under the basalt cover established as forming the floor of the fjords.

\section{Ship-borne survey in Fønfjord}

A minor magnetic survey was carried out in two areas in, respectively, the innermost and the outermost part of Fønfjord, aimed at identifying the possible existence of Tertiary basic volcanic units in the fjord. Geologically this part of the region comprises crystalline rocks, mainly migmatites and granites, which are capped by a several hundred metre thick sequence of Tertiary plateau basalts at altitudes of $1000-1500 \mathrm{~m}$ height. The existence of possible volcanic bodies was suggested by W. S. Watt (pers. communication), who had observed a rapid decrease in thickness of pyroclastic horizons away from the suggested Fønfjord 
localities (Watt \& Watt, 1971). The expected magnetic contrast between basalts and crystalline rocks was expected to facilitate the identification of possible units.

The survey was undertaken from an 8 tons motor cutter using the same methods and equipment as the other ship-borne programme. However, the navigation and position identification was in this case only made using compass and visual bearings, which proved sufficiently accurate in the narrow fjords.

The interpretation of the anomaly map which resulted from this part of the survey has not been finalised, but in both the investigated areas, i.e. near Hjørnedal and north-west of Danmark $\varnothing$, magnetic anomalies suggesting the presence of basalts have been found.

\section{References}

Henriksen, N. \& Higgins, A. K. 1970: Preliminary results of mapping in the crystalline complex of Renland, the southern Stauning Alper and south-west Liverpool Land, Scoresby Sund, East Greenland. Rapp. Gronlands geol. Unders. 30, 5-17.

Kempter, E. 1961: Die jungpaläozoischen Sedimente von Süd Scoresby Land. Meddr Grønland $164,1,123 \mathrm{pp}$.

Watt, W.S. \& Watt, M. 1971: Preliminary report of the mapping of the basalts of parts of Milne Land and Gåseland. Rapp. Gronlands geol. Unders. 37, 42-50. 